\title{
A LADY, HER PHILOSOPHER AND A CONTRADICTION
}

\section{Alan SCHWERIN ${ }^{1}$}

Philosophy / Monmouth University

West Long Branch, NJ 07764-1898, USA aschweri@monmouth.edu

I endeavour to go by reason as far as possible. ("Greek Exercises" [1888], Papers I: II)

There can be no doubt that I9II was a productive and tumultuous year for Bertrand Russell. Towards the end of the year he has the following to say about his productivity:

During the past year I have written 3 Paris lectures (of which 2 are published and the 3 rd soon will be), ${ }^{2}$ my shilling shocker [i.e. The Problems of Philosophy], the Aristotelian paper, ${ }^{3}$ and [the I29-page manuscript entitled] "Prisons". Con-

' I must thank the staff in the Ready Division of Archives and Research Collections at McMaster University Library for their assistance in gathering the information I needed for this paper. I am particularly indebted to Carl Spadoni and Ken Blackwell for all their help. All original correspondence quoted is in the Bertrand Russell Archives.

A grant from the Aid-to-Creativity Committee from Monmouth University (New Jersey) made this project possible.

2 "Le Réalisme analytique", Bulletin de la société française de philosophie (I9II); "L'Importance philosophique de la logistique", Revue de métaphysique et de morale (1911); "Sur les axiomes de l'infini et du transfini", Société mathématique de France, Comptes rendus des séances (I9II) -all reprinted in Papers 6.

3 The paper was entitled "On the Relations of Universals and Particulars" and was read at the annual meeting of the Aristotelian Society on 30 October I9II and published the following year in their Proceedings. Russell, as newly elected President of the Society, had to hold their meeting on "the last Monday of October to suit the everlasting [Henri] Bergson, who would then be present" ( $S L B R$, I: 393 , letter \#177 to Lady Ottoline Morrell, [r6 Sept. 19ri]) 
sidering how much time has been taken up in lectures and proofs [i.c. proofreading for the gargantuan Principia Mathematica] and seeing pupils, ${ }^{4}$ I don't feel seriously dissatisfied.

The intense scholarly activity in 1911 that resulted in an impressive set of diverse academic publications and manuscripts was accompanied by a number of personal entanglements that were equally intense and also tumultuous for Russell. Two of these relationships would prove to be especially strained. Late Wednesday afternoon, I8 October $\mathrm{x} 9 \mathrm{II}$, Russell met Ludwig Wittgenstein for the first time. As we know from the numerous accounts available on their relationship, the exchanges between Russell and Wittgenstein were emotionally charged and not always cordial. However, in I9II a second relationship flourished that would prove equally intense.

Earlier in the year, Russell renewed his acquaintance with Lady Ottoline Morrell, thereby setting in motion a liaison that would last six years and a friendship that would last a further twenty-one years. ${ }^{6}$ The rela-

${ }^{4}$ One needs to view this reference to the demands made on him by his students with some circumspection. In a letter to a lifelong friend, Lucy Donnelly-an American professor of literature teaching at Bryn Mawr College-Russell allows some light in on his commitments to teaching: I am very busy and very happy. I enjoy my young men very much. Only two stuck to my lectures to the bitte bed lastear hie. the acadoy my no doubt diminish soon. (SLBR, I: 402; my emphasis and insertion)

Classes this size are not exactly overwhelming, as Russell himself seems to intimate. The two students who received fellowships were C. D. Broad, the philosopher, and E. H. Neville, a mathematician.

SSLBR I: 403 , letter \#286 to Morrell, $\mathrm{r}_{3}$ Dec. I9II; my insertions. In what follows, the use of square brackets denotes my insertions.

${ }^{6}$ Lady Ottoline Morrell died in 1938 under unusual circumstances. Her husband, Philip Morrell had fallen ill and visited a specialist with Lady Ottoline. The doctor bluntly informed both of them that Philip had a serious heart disease and that he had only six months to live. On hearing the news, Lady Ottoline broke down, and for a time partially lost the use of her limbs. To recover, she went to a nursing home for treatment from a long-standing and trusted doctor. To her dismay, she learned that be had suddenly died. Given her wcak condition, this news apparently overwhelmed her, and she died shortly thereafter. As her editor, Robert Gathorne-Hardy, writes: "This news [about the death of the doctor], which must have struck her, not only as the loss of a friend but also as the irremediable and ultimate denial of health, was too much, and within a short time tionship would generate a correspondence in excess of 3,400 letters, telegrams and postcards. ${ }^{7}$ Both Morrell and Wittgenstein would leave indelible marks on Russell. My paper is an assessment of the impact of Morrell on Russell's thought. In particular, I shall attempt to accomplish two tasks in this paper:

(I) In the first place, I shall show that Russell's r9ir view of philosophy appears to be contradictory, especially in regard to his conception of the Self.

(2) In the second place, I shall consider the nature and extent of Morrell's influence on Russell's rgrr view of philosophy.

My central thesis is that Russell's conception of philosophy shifts significantly in 19II-a shift in large measure due, or so I argue, to the ramifications of the intense personal relationship that developed between Russell and Morrell at this time. As Miranda Seymour points out in her biography, Ottoline Morrell: Life on the Grand Scale, the year I9II "marked the end of what [Russell] described as his imprisonment in 'that cold and unresponsive love' [with mathematics] and the beginning of his larger ... more important career as a philosopher concerned with human matters. His love for Lady Ottoline played a significant part in his transformation." ${ }^{8} \mathrm{My}$ thesis is that this radical, and contradictory, transformation manifests itself where we might least expect to find it: namely, in a compact, self-contained text less than Ioo pages in length. I shall show that The Problems of Philosophy presents two views of the Self that do not appear to be consistent. Given the centrality of these views on the Self in his conception of philosophy, it also appears that Russell's I9II conception of philosophy is inconsistent. Let me begin with a con-

she died" (Ottoline: the Early Memoirs of Lady Ottoline Morrell [London: Faber and Faber, 1963], pp. 60-I).

7 In her biography of Lady Ottoline, Sandra Darroch points out that both Russell and Lady Ottoline were prolific correspondents. The Harry Ransom Humanities Research Center at the University of Texas at Austin contains over 1,900 letters from Russell to Lady Ottoline-spanning the period I9II to I938 -while some I,500 letters from Lady Ottoline to Russell are housed in the Russell Archives at McMaster University. See Darroch, Ottoline: the Life of Lady Ottoline Morrell (New York: Coward, McGann \& Geoghegan, 1975), p. I2.

${ }^{8}$ New York: Farrar Straus Giroux, I992, p. IIs. 
sideration of Russell's conception of philosophy as he articulates it in his correspondence and in the shilling shocker, The Problems of Philosophy.

\section{ON RUSSELL'S I9II CONCEPTION OF PHILOSOPHY:} THE FIRST PHASE

The correspondence we have on the origins of The Problems of Philosophy leads one to suspect that Russell was reluctant to write the book. In a letter written from Castle Howard, York, on 12 September 19Io, Professor Gilbert Murray - a friend of Russell's and an editor for The Home University Library series, published by Williams and Norgate-suggests that Russell write something for his series. Murray clearly anticipates some resistance from the co-author of Principia Mathematica to produce a popular text, because in his letter Murray goes out of his way to reassure Russell about the merits of the project. After extolling the virtues of the enterprise, Murray resorts to flattery to sell Russell on the idea of a popular academic text. Subtly announcing that the publishers are intent on getting "the best minds of the country into direct touch with the great masses of people who now read Harmsworth or nothing at all", Murray goes on to invite Russell to "see if there is not anything that you want to say to 75,000 people." In Murray's opinion, if anyone can reach out to an audience this large, Russell can. Murray's initial plan was for Russell to write about mathematics:

Can you do anything [for the series]? Principles of Mathematics or anything else? It is possible, you know, and you could do it if anyone can. I am going to do Greece and [another editor] Fisher [will do] European History. (Letter of I2 Sept. 1910, B RA REC. ACQ. 7I)

When Russell rejects the suggestion from Murray that he write a popular text on mathematics, Murray pursues another tack in his next letter:

If you don't want to tell them what Mathematics is, can you not tell them what Philosophy is? You could do it with great detachment from the conventional schoois, and you could put all the main problems in their very lowest terms. (Letter of ig Sept. I910)

Murray is clearly determined to secure Russell's services! To help seal his case, he asks rhetorically whether Russell can identify any orher philos- opher who is

I. completely alive and original; 2 . democratic, so that he wants to communicate his thoughts to shop-assistants; 3. sharp-edged and not wobbly or sloppy in thought. (Ibid.)

If Russell can come up with another name, Murray promises to "cease to persecute" him. Wirh cajoling like this, Russell finds it difficult to resist Murray's overtures. He reluctantly decides to accept Murray's proposal to write a popular book on philosophy that shop assistants could read in their armchairs and not find "wobbly or sloppy in thought".

Russell's earlier heroic struggle with Alfred Whitehead over the monumental Principia Mathematica-the daunting, three-volume investigation of the foundations of mathematics, with its elaborate formal notation-had clearly taken its toll: "... my intellect never quite recovered from the strain. I have been ever since definitely less capable of dealing with difficult abstractions than I was before" (Auto., I: I53). Murray's request that Russell write the non-technical, popular, and presumably undemanding shilling shocker then seems to come at an opportune moment. His initial reluctance notwithstanding, Russell would later speak very favourably about the invitation to write a popular work in philosophy. In his view, this modest text afforded him an opportunityand he admits this with some surprise- to write on the really important issues. As he later puts it to Morrell, in a letter written four months after the completion of the book:

The shilling shocker really seems to me better worth doing [than my technical work]. It is all puzzling and obscure. For many years I have had absolutely no choice as to work-[so much so] that I have got out of the way of wondering what is best to do. I think really the important thing now is to make the ideas I already have intelligible. And I ought to get away from pedantry. My feelings have changed about all this; I did think the technical philosophy that remains for me to do very important indeed. (SLBR, I: 403-4, letter \#286, I3 Dec. I911; my emphasis)

Thus Russell's assessment of the importance of his technical work changed as a result of The Problems of Philosophy. From now on Russell would view non-technical popular philosophy more favourably. By midDecember I9II Russell's views have changed to such an extent that he is 
willing to concede that

.. technical refinements add very little except controversy and long words. I was reinforced in this view by finding how much I could say on [philosophical questions] in the shilling shocker. (Ibid.)

All this suggests that The Problems of Philosophy marks a watershed in Russell's philosophical development. Ultimarely the book proved far more satisfying than he initially anticipated. But what does Russell actually accomplish with this modest popular text?

In the end, The Problems of Philosophy-which took approximately eight weeks to write-comprised some 46,000 words. Divided into fifteen essays on a variety of philosophical issues, the text enables Russell to explain and show what philosophy is in a manner that even unsophisticated readers could comprehend. ${ }^{\text {IO }}$ His conception of philosophy emerges early on, for the opening paragraph of The Problems of Philosophy presents the reader with a bold statement on philosophy: "philos-

9 We can be faitly sure that Russell finished writing the manuscript on 12 August InIr In a lorter to Murray on this date Russell expresses his pleasure to learn that Murray is satisfied with the work he has seen so far: "I am greatly relieved that you like the stuff. I send you chap. XII which you ought to have had before; also another copy (corrected) of XIII and Xrv. Please send me the copy of those you already have. (Trinity is still my best address.) Chap. $x v$ (the last) is written and should reach you in a day or two."

Russell was correct about the final chapter (for more detail, see my final footnote). As for the beginning of the text, the evidence is less definitive. In a letter to Morrell on I Jor the bing socker, but says nothing about his June he (disapprovingly) refers to Moore's shilling shock, by own book. This suggests that Russell had not started his book by the ist. The first reference I am aware of to The Problems of Philosophy as a manuscript in progress is in a letter to Morrell on 24 June, when Russell writes the following:

I am getting on with my book. Would you like to see what exists, still rough, and going to be improved? Or shall I wait till it is in the more final shape? As I am not to deal with either religion or imprest morals Thus there is not much scope for much that might otherwise be said. (Letter \#126)

While the references here are admittedly not explicit, Russell is surely referring to The Problems of Philosophy.

ro As I have pointed out elsewhere, the conception of philosophy that is articulated in Russell's shilling shocker has been very influential. See my "Critical Thinking and Philosophy: Some Remarks on Russell's Views", The Bertrand Russell Society Quarterly, no. IOO (Nov. 1998): 7-16. ophy is merely the attempt to answer ... ultimate questions" ( $\left.P P_{3}, \mathrm{p} . \mathrm{r}\right)$ But the philosophical enterprise, continues Russell, is characterized by a unique approach: these fundamental questions are scrutinized critically. Unlike our (apparently) careless and dogmatic efforts "in ordinary life and even in the sciences", philosophers "explor[e] all that makes [their ultimate] questions puzzling" (ibid.). But unfortunately, philosophers have so far made little progress in their endeavours. In his analysis Russell is candid about the past successes of philosophers - their accomplishments are few and far between:

... it cannot be maintained that philosophy has had any very great measure of success in its attempts to provide definite answers to its questions. ( $P P_{3}$, p. 90)

How does Russell account for this difficulty to solve philosophical questions? While he does not provide us with a specific explanation for this shortcoming with our philosophical questions, the text suggests an answer.

There can be little doubt that, as far as Russell is concerned, the lack of progress in philosophy can be traced to a primary source: namely, our ordinary ideas. And problems in this quarter fuel the problems in philosophy. Adopting the fundamental thesis that vagueness and confusion underlie our non-philosophical ideas-and thus that our ordinary ideas are similarly confused and vague-Russell attempts to show his readers that even the most mundane idea can be regarded as logically defective. As he sees it, even a cursory exposure to philosophical analysis can reveal "all the vagueness and confusion that underlies our ordinary ideas" $\left(P P_{3}\right.$, p. I; my emphasis). But if Russell is intent on defending a thesis on the status of philosophical questions-and thus presumably on the status of philosophical ideas -and if his argument centers on references to ordinary ideas, he must be committed to a thesis on the tight relationship between philosophical ideas and ordinary ideas. For if philosophical questions are puzzling by virtue of the defective ordinary ideas we rely on in non-philosophical contexts, there must surely be a strong similarity between philosophical and non-philosophical (or ordinary) ideas. While not necessarily committing himself to the radical suggestion that there is no difference between these two sets of ideas, Russell's line of reasoning in the opening section of The Problems of Philosophy strongly suggests that for him our ordinary ideas are the misleading naïve precursors of 
our more refined, yet problematic, philosophical ideas.

From this it follows that Russell views all questions as initially vague and confused. So our failure to engage in careful critical investigations of both the philosophical and non-philosophical questions that interest us will inevitably leave us in a most pernicious state: namely, confusion! Without the requisite critical analysis, regular citizens-such as Russell's shop assistants-will continue to face the very same predicament that philosophers (apparently) face. Whether we are naïve shop assistants or sophisticated philosophers, it is thus incumbent on all of us to critically investigate our questions, thereby enabling us to learn about our defective ideas. The proposal that we realize the confusion and vagueness tive ideas. The proll's account of philosophy. Before I consider some of these consequences, I want to outline the reasons Russell provides in The Problems of Philosophy for this view.

What, then, leads Russell to conclude that our ordinary ideas are problematic?

Russell's argument for the thesis that our ordinary ideas are logically defective, or "vague and confused", is a variant of the argument from illusion. Consider the famous example that Russell provides in the first chapter of The Problems of Philosophy. While writing his chapter, Russell looks around him and remarks on the items that he perceives around him on the desk, in the room and beyond. If we could ask him to tell us what it is that he is looking at, he might reply as follows: "I am looking at a table." Now suppose we press him to be more specific about the object he perceives. Russell's assessment of the properties of the object that he apparently is looking at will be significantly influenced by a that he apparently is looking at we foctors. To mention a few he overwhelmed by the bright light from the window, and reply that the table is a faint dark blur. Or he might be under the impression that it has a smooth top surface, when closer inspection reveals otherwise. Or he might be sick, and conclude that the table has a yellow tint, while another person with a different ocular condition might conclude that the table is pink. Someone with poor vision might see a fuzzy soft object in the corner of the room, while another sees a sharp, precisely defined object. Russell might see an oblong table, while a friend in a different section of the room might argue that the table is square. Talking about observations of colour, Russell maintains that
.. colour is not something which is inherent in the table, but something depending upon the [object] and the spectator and the way the light falls on the [object]. When, in ordinary life, we speak of the colour of the table, we only mean the sort of colour which it will seem to have to a normal spectator from an ordinary point of view under usual conditions of light. But the other colours which appear under other conditions have just as good a right to be considered real.... ( $\left(P P_{3}\right.$, pp. 2-3)

This diversity of possible observations leads Russell to conclude that our grasp of reality is not as secure as we initially thought. Our ideas of reality, both philosophical and non-philosophical, are obscure: this is a fundamental shortcoming that manifests itself most forcefully when we attempt to articulate our thoughts about the objects perceived. Many statements of the objects and their characteristics can be produced, each possessing at least an initial plausibility. The multiplicity of possible answers that can be produced in response to questions about our observations of the contents and properties of our world leads Russell to conclude that the probability of any one statement being correct is very low. As he bluntly puts it, "any statement as to what it is that our immediate experiences make us know is very likely to be wrong" (ibid., p. I). ${ }^{\text {II }}$

But this argument to show that our ordinary ideas are confused is central to Russell's overall concern in the first chapter to discover knowledge that is certain. We need to recall that the very first sentence of The Problems of Philosophy is a fundamental question about knowledge and certainty: namely, "Is there any knowledge in the world that is so certain that no reasonable man could doubt it?" Russell's graphic illustration that even mundane perceptual acts of tables are complex activities, capable of generating bewildering possibilities for both the perceiver and the analyst, is clearly designed to suggest a negative answer to Russell's opening question. While he never does offer an explicit response to his leading question, the analysis that follows his opening question strongly suggests that there will always be room for doubt.

Now it is important to note that the complexities that Russell alludes to in his famous perceptual example, with their concomitant uncer-

"I am not concerned here with the validity of Russell's argument on this issue. The shift from remarks on the possibility of many statements about an object to the suggestion that they or that any one is "very likely to be wrong" appears unwarranted and could undermine Russell's conclusion here on the accuracy of our perceptual reports. 
tainties, compel him to retreat to a more abstract philosophical plane that he appears to find less uncertain. While knowledge of the (regular) world of tables and chairs is uncertain and marked by confusion-due in large measure to our "confused and vague" ordinary ideas-knowledge of the (non-regular, or philosophical) world apparently offers at least the possibility of certainty and clarity. From the (presumably more secure) vantage point of this philosophical world, or perspective, statements about perceptual acts can now be produced that are free of the uncertainties that characterize non-philosophical statements. From the lofty philosophical perspective perceptual acts and their world can now be analyzed and written about with a degree of certainty and precision unheard of in the non-philosophical world. In short, Russell's decision to adopt the philosophical framework, according to which individuals who perceive a world are interpreting sense-data that have perhaps been caused by objects in the external world, is a decision to choose a framework that Russell assumes "no reasonable man could doubt." Irrespective of our diverse (and thus questionable) assessments of the external world's objects and properties, we (apparently) can be sure that perceptual acts involve sensations that provide us with sense-data that need to be interpreted. How we interpret the sense-data appears to be of little consequence to Russell. ${ }^{\mathrm{I2}}$ That we have the sense-data, however, does seem significant for Russell, for throughout his analysis, and especially in his concluding remarks in this section, he assumes that their presence in perceptual acts cannot be disputed. ${ }^{13}$ This division between the two worlds - the uncertain ordinary world of tables, and the less uncertain philosophical world of sense-data-comes through most forcefully in Russell's conclusion on perceptual acts. Referring to the perception of his table, he says the following:

${ }^{12}$ Russell briefly runs through a few possible interpretations of sense-data, invoking the views of Berkeley and Leibniz in the process.

${ }_{13}$ What are sense-data? Russell reifies them as things, unlike sensations that are processes of our consciousness:

Let us give the name of "sense-data" to the things that are immediarely known in sensation: such things as colours, sounds, smells, hardnesses, roughnesses, and so on. We shall give the name "sensation" to the experience of being immediately aware of these things. Thus whenever we see a colou we have a sensation of the colour, but the colour itself is a sense-datum, not a sensation. $\quad\left(P P_{3}, \mathrm{p} .4\right.$ my emphases)
Thus it becomes evident that the real table, if there is one, is not the same as what we immediately experience by sight or touch or hearing. The real table, if there is one, is not immediately known to us at all, but must be an inference from what is immediately known. (PP, pp. 3-4)

What are immediately known, presumably, are the sense-data that we have experienced. Unlike our uncertain accounts of the table and its properties, our accounts of the sense-data that we encounter immediately can be certain.

In critically reflecting on his perceptions of his world Russell intimates that he has unearthed a world of definite sense-data that promise the certainty denied him in his other, more mundane non-philosophical world. The retreat to this world of private sensations and sense-data, as I see it, leads Russell to assume that he has found a world that now offers at least the prospects of certainty and the elimination of confusionprospects denied those who remain content with the mundane world of physical objects. In short, it appears that Russell's world of private sensedata and sensations is his philosophical Eldorado-a fantastic world less encumbered by the defects that beset ordinary perceivers in their nonphilosophical world of physical objects.

On this interpretation, there now appears to be a serious problem with some of the later pronouncements on philosophy in The Problems of Philosophy. The fifteenth chapter, which is entitled "The Value of Philosophy", manifests this tension most explicitly, in my view. Let me say a little about this final chapter and show how it departs from some of his earlier pronouncements on philosophy.

\section{ON RUSSELL'S I9II CONCEPTION OF PHILOSOPHY: THE SECOND PHASE}

In the final chapter Russell asserts that "philosophy ... aims primarily at knowledge" (p. 90), but he adds that this knowledge will not emerge from the contemplation of the Self. Those philosophies that begin with a consideration of the Self yield false-knowledge:

What [this philosophy that is founded on the Self] calls knowledge is ... a set of prejudices, habits, and desires, making an impenetrable veil between us and the world beyond. The man who finds pleasure in such a theory of knowledge is 
like the man who never leaves the domestic circle for fear his word might not be law. $\left(P P_{3}\right.$, p. 93)

Relying on the contentious assumption that philosophical inquiries that begin with a consideration of the Self are confined to a consideration of the Self, Russell decries the parochialism he views as integral to this approach. Putting it rather bluntly, Russell asserts that "greatness of soul is not fostered by those philosophies which assimilate the universe to Man" ( $P P_{3}$, p. 92). ${ }^{\mathrm{I}}$ Genuine knowledge, on the other hand, insists Russell in Chapter $\mathrm{xV}$ of The Problems of Philosophy, must begin with a consideration of the external world, i.e. the not-Self. The investigation of the external world will, apparently, help to determine the parameters of our private worlds:

In contemplation ... we start from the not-Self, and through its greatness the boundaries of Self are enlarged; through the infinity of the universe the mind which contemplates it achieves some share in infinity. (Ibid.; my emphasis)

Rather than initiating our investigation from the Self-a procedure that apparently "is a form of self-assertion ... [that] ... is an obstacle to the growth of Self which it desires ...", we ought to "start from the not-Self" (ibid.). To begin from the Self is to demean the external world, in Russell's view:

Self-assertion, in philosophic speculation as elsewhere, views the world as a means to its own ends; thus it makes the world of less account than Self, and the Self sets bounds to the greatness of its goods. (Ibid:; my emphasis)

This reliance on the Self as an Archimedean point has the effect of imprisoning the mind, suggests Russell, "since it fetters contemplation to Self" (ibid.). Unfortunately, this contemplation will inevitably be distorted and subservient to instinct, self-interest and desire. In short, a barrier will arise "between subject and object", thereby converting our personal and private worlds into "a prison to the intellect" (p. 93).

These are strong words! But is this account of the Self consistent with

14 Inquiries that begin from the Self, according to Russell, inevitably "try to show that the world is so similar to this Self that knowledge of it is possible without any admission of what seems alien" (ibid.).
Russell's earlier analysis of perception and the central role played by sensations and sense-data? It would seem not. Did Russell not advise us to retreat from the uncertain world of tables and physical objects to the private world of sense-data and sensations in the opening chapter of The Problems of Philosophy? Did his analysis not suggest that this philosophical world offers at least the prospect of certainty and clarity-prospects (apparently) denied our other, non-philosophical world? But the world of sense-data and sensations is the world of the Self-the very same world that in the final chapter of his shilling shocker Russell pejoratively characterizes as restrictive and contaminated. All this suggests that there is a tension, if not an outright contradiction, between the first and final chapters in The Problems of Philosophy. The evidence above appears to support the view that Russell's 19II account of philosophy has shifted significantly in the course of the eight weeks that it took to produce the shilling shocker. How do we account for Russell's evolving assessment of the Self in his conception of philosophy? I would like to say a little on this important issue.

\section{ON RUSSELL'S EVOLVING ASSESSMENT} OF THE SELF IN IOII

Why did Russell's view of the Self-and thus his broader view of philosophy-change so drastically in r9u? While numerous explanations for this contradictory transition can be given, two strike me as particularly plausible. For convenience, I shall label these explanations "the certainty explanation" and "the Lady Ottoline explanation". As I shall demonstrate, these are not mutually exclusive explanations. Consider the first one.

Perhaps Russell's assessment of the role of certainty in philosophy changed between the first and the final chapters of The Problems of Philosophy. While the concern with certainty appears to underlie the argument from illusion, as I have suggested above, the final chapter stresses speculation, creativity and the liberalization of the minds of those that pursue philosophy. These latter themes tend not to be associated with the constraints imposed by an emphasis on certainty. As a matter of fact, in the fifteenth chapter Russell goes as far as to celebrate uncertainty in his account of the value of philosophy: 
The value of philosophy is, in fact, to be sought largely in its very uncertainty. (PP, p. 9I; my emphasis)

So perhaps Russell's view of the Self (and thus of philosophy) evolved because his assessment of certainty changed between the composition of the first and the final chapters of The Problems of Philosophy.

As it happens, Russell himself offers an explanation elsewhere that takes this tack. In a postscript to his Autobiography, which has been published separately as an essay entitled "Reflections on my Eightieth Birthday" in Portraits from Memory, Russell, much to my delight, draws attention to a significant modification in his views on philosophy:

$U_{p}$ to the age of thirty-eight I gave most of my energies to the [question "whether anything could be known"]. I was troubled by scepticism ... I wanted certainty in the kind of way in which people want religious faith.... But as [my] work proceeded, I was continually reminded of the fable about the elephant and the tortoise. Having constructed an elephant upon which the mathematical world could rest, I found the elephant tottering, and proceeded to construct a tortoise to keep the elephant from falling. But the tortoise was no more secure than the elephant.... (PfM, p. 53, Auto., 3: 220; my emphases)

The Problems of Philosophy was written the year Russell turned thirtynine. It seems reasonable then to infer that the fault-line in his views on certainty-and hence in his views on philosophy in general-can be traced to this popular text. There appear to be good reasons for suggesting that Russell's views on the Self and of philosophy changed in the shilling shocker because of his reassessment of the role of certainty in philosophy

As plausible as this explanation might appear, it still leaves unanswered the more fundamental question on the transition of Russell's views in The Problems of Philosophy. At least one virtue of the Lady Ottoline explanation is its ability to account for both Russell's evolving assessment of certainty in philosophy and the modification of his views on the Self. Without further ado, let us consider Lady Ottoline Morrell's influence on Russell's thought in I9II.

Lady Ottoline Violet Anne Morrell was a year younger than Russell. By all accounts she was a frail, lonely child. Her father, Lieutenant-General Arthur Bentinck, died when she was four, and as Nicholas Griffin points out, "her brothers, all older than she, were away much of the time and ignored her when they were not" (SLBR, r: 345). These remarks on her youth are borne out by Lady Ottoline herself. For instance, her autobiography contains many references to her lonely escapades in Welbeck Abbey-an impressive, expansive estate that she moved to with her mother when she was six.

By her own account, her formal education left much to be desired. Attended to by "numerous private governesses", who apparently were more intent on inculcating the requisite etiquette than educating her, Lady Ottoline received little more than a rudimentary exposure to the three R's. Griffin puts it plainly: "She was brought up to be the wife of an aristocrat and her education was limited to what was thought necessary for this role, that is, to virtually nothing at all" (ibid.). Lady Ottoline was acutely aware of these educational limitations, and throughout her extensive correspondence with Russell she draws attention to her "educational shortcomings". She routinely decries the letters that she sends Russell, regarding them as poor inarticulate attempts to express her innermost thoughts. Here are a few of many possible examples of her exasperation in 19 II.

On Monday morning, 27 March, she writes:

This is a horrible bald letter but I can only write these crude sentences today. (Letter 710.081287)

On Friday morning, 3I March, she writes:

I find it so difficult to put into words ... but somehow I believe you know what I feel.... Every word of your letter seems sacred to me. If I could express myself they are the words I should like to say to you.... As I read this letter it seems utterly cold and stupid. I don't feel like that Bertie. ${ }^{15}$ (Letter 710.081290)

On Tuesday, 25 May, she writes:

... I cannot enlarge on all that is going on within me now but I think you know my Bertie it is all good. (Letter 710.081370)

${ }^{15}$ These extracts are from letters to Russell by Lady Ottoline Morrell in the Bertrand Russell Archives. They are quoted with the kind permission of her grandson, Adrian M. Goodman. 
On is July from Peppard Cottage, Henley-on-Thames:

I am not sure about asking you questions. I think when the time comes you will tell me without.... (Letter 710.081444)

Two letters written on 5 and 6 March 1912 on the lost manuscript Prisons are the longest letters written by Lady Ottoline to Russell in the first year of their relationship. These letters are the most critical in her correspondence, yet they also happen to be the most tentative. There are constant references to her "stupidity", she mentions her "foolish remarks" on his text, and her suggestions on Prisons, while detailed, are invariably very hesitant (letters 710.081657 and .081658).

Most of her letters to Russell express similar frustrations with her inability to express herself. The editor of her memoirs, Robert GathorneHardy, attributes this difficulty to her inadequate education at Welbeck:

Her education, in respect to her powers and her ambitions, was defective. It was the result of this, I think, which gave her a smaller vocabulary than might have been looked for in one so widely read. (Ottoline, p. 2I)

These brief glimpses into her correspondence with Russell compel us to consider the following important question: how could Lady Ottoline, with her severely limited formal education, have had any impact, let alone a significant one, on the philosophical thoughts of one of the twentieth-century's greatest intellects?

In a word, the answer is religion. Lady Ottoline developed a deep and abiding interest in religion in her teens. This interest-perhaps "passion" is not an inappropriate term-became the focal point of her relationship with Russell in I9II. Initially fuelled by Thomas à Kempis's The Imitation of Christ, her religious interests began to flourish after she met an Anglican nun, Mother Julian. While visiting the Sisterhood (or convent) in Truro in I894, Lady Ottoline met Mother Julian and set in motion a friendship that would last seventeen years. This especially significant relationship for Lady Ottoline lasted until the death in Seprember I9II of Mother Julian. In her memoirs Lady Ottoline writes warmly of her dear companion:

... Mother Julian, one of the people I have loved most in my life. [My memory of] [m]y cousin fades away, and I can only remember the little frail figure of
Mother Julian, almost lost in her voluminous nun's draperies ... the face extremely wrinkled and soft, with amazing eyes.... They had seen the full pain and light of life, still saw the light, and still felt love and reverence. (Ottoline, pp. 96-7)

It was the Anglican nun, Mother Julian, that provided Lady Ottoline with the warm companionship absent from her youth, and it was Mother Julian who, more importantly, helped nurture Lady Ottoline both spiritually and intellectually: "it was to Mother Julian that I owe the adjustment of my intellectual and aesthetic side" (ibid., p. 98). Irrespective of the large, flamboyant "Bloomsbury gatherings" that would congregate at Peppard Cottage at Henley-on-Thames or at 44, Bedford Square, London, Lady Ottoline drew comfort from her close relationship with Mother Julian. In her memoirs, while reminiscing about her friends, Lady Ottoline makes a point of identifying two people who were especially important in her life. Both of these friends are clerics. In a chapter that encompasses references from her youth to the time of Mother Julian's death, ${ }^{16}$ Lady Ottoline identifies a surprisingly small group of friends: "My aunt and cousins at Ham Common and mother Julian were the only people that I was friends with ${ }^{17}$ except, I remember, the late Archbishop of York ..." (ibid., p. 98). This is a revealing account of her friends, both in terms of who is on and who is off the list. Individuals who are spiritually inclined are included in the list of true friends, and someone we might have expected to find on the list has been left off: namely, Bertrand Russell. What this all suggests is that Lady Ottoline Morrell was a deeply spiritual woman, impatient with linguistic and intellectual issues, and more concerned with emotional and religious concerns.

${ }^{16}$ In her memoirs Lady Ottoline incorrectly identifies Mother Julian's death-date as 1912. This year does not square with her correspondence with Russell, where her letters from early September I9I make reference to the death of Mother Julian.

${ }_{17}$ Lady Ottoline did not view the large gatherings at her home as especially significant occasions, as far as I can tell from her correspondence-at least that with Russell. A most revealing account of one of these social meetings was written to Russell on Is July I9Ir: "We talked politics all the evening. I longed for you. It is a great sadness to me that you are never present at my general talks for one reveals oneself so much when one is able to hide behind a company and dart out now and then, and I cannot help thinking often, oh what a waste that he is not here, but I must be patient and I expect it will come" (letter 710.081444). 
As it happens, this is clearly how Russell began to see Lady Ottoline. As the intense passion of late March and April r9I subsided, Russell slowly realized that his lover had a deep spiritual nature-a spirituality that clearly influenced, if not later completely determined, their relationship. As has been pointed out in a fascinating psychological analysis of the relationship between Russell and Morrell, religious considerations would come to dominate the relationship between the two:

However infatuated [Russell] may have been with Ottoline at the beginning, as the relationship developed her spiritual nature would prompt him to tackle serious problems associated with religion. ${ }^{18}$

While both parties were interested in religion, the magnet, or so it appears, became Lady Ottoline's spirituality. As Miranda Seymour puts it-perhaps a little too enthusiastically-it was Russell who was drawn in by Lady Ottoline, and not the other way round. Throughout their relationship,

Ottoline never compromised her [religious] beliefs. It was Bertie who, under her strong influence and in response to his desperate need to find an area in which they could reach agreement, gradually moved away from the cosmic loneliness he had bravely confronted in one of his early and most admired writings, "A Free Man's Worship". (Ottoline Morrell, p. I23; my emphasis)

Reluctant to accept that she was influencing him intellectually, Russell nevertheless does concede that his relationship with Lady Ottoline changed him. ${ }^{19}$ As he begrudgingly puts it, her influence was "almost wholly beneficial". ${ }^{20}$ While we might quibble about the nature and

${ }^{18}$ The analysis is in Maria Forte's unpublished master's thesis, "Creativity in the Relationship between Bertrand Russell and Lady Ottoline Morrell" (McMaster U., 1983; copy in Russell Archives). The quotation is from p. 78.

19 In her biography of Lady Ottoline, Seymour suggests that "Russell scholars have been understandably reluctant to stress the influence of a woman who is usually seen as a figure of fun" (p. 4). But as she sees it, "it is not only the scholars that are reluctant to concede Lady Ottoline's impact on him, Russell himself, apparently, did everything he could in later life to obliterate the most extreme examples of Ottoline's intellectual influence over him as she encouraged him to give voice to the mystical side of his nature" (p. I24). This is an interesting issue that cannot be considered here.

20 Auto., I: 214. This influence would sometimes be direct, sometimes indirect. Lady depth of her impact on him, there can be little doubt that Lady Ottoline had a great influence on Russell in 19II-an impact due, in large measure, to her (unwavering) religious views.

Now Lady Ottoline's interest in, and remarks on, religious matters did not fall on barren ground. Far from it. Russell had long had an abiding interest in religion. For instance, his youthful "Greek Exercises" is dominated by his views on God, religious belief and arguments on God's existence, and the extensive reading list that he compiled on what he read between 1891 and 1902 is replete with references to religious texts. ${ }^{2 \mathrm{I}}$ Furthermore, and most important in this context, Russell frequently mentions Spinoza and his God to Lady Ottoline. As their relationship matured Russell took it upon himself to gently inject more and more philosophy into their correspondence-and the philosopher that features most prominently in this correspondence in the first half of I9Ir is the deeply religious philosopher, Baruch Spinoza. ${ }^{22}$ In addition to numerous brief references to Spinoza in this correspondence, the only occasions where he considers the thoughts of a philosopher in some depth with Lady Ottoline occur when Russell deals with Spinoza's thought. On 24 May I9II, for example, Russell provides her with a detailed account of his understanding of Spinoza's conception of "the intellectual love of God". On Io July, while staying at Upper Wyche, Russell enthusiastically writes about the philosophers he would like to

Ottoline's later involvement in the creation of "The Perplexities of John Forstice", for instance, is an example of direct intervention that Russell would come to regret. As he ruefully purs it, "the second part [of Forstice] represented my opinions during only a very short period. My views in [it] were very sentimental, much too mild, and much too favourable to religion. In all this I was unduly influenced by Lady Ottoline Morrell" (Papers 12: 127).

${ }^{21}$ The reading list is published under the heading "What Shall I Read?", Papers I: 353 ff.

${ }^{22}$ Not all commentators regard the relationship in this light. In his work on the role of Spinoza in Russell's thought, The Spinozistic Ethics of Bertrand Russell (London: Allen and Unwin, 1985), Ken Blackwell suggests that it was Spinoza's ethics that both attracted Russell and became central in the relationship between Russell and Lady Ottoline. As Blackwell puts it, "The place of honour [accorded Spinoza] can be explained only by the extremely high regard in which Russell holds Spinoza's ethical contributions" (p. 72, my emphasis). This interpretation does not appear that different to mine if we remember that the person who seeks to understand [Spinozas] God-i.e. the universe-seeks to acquire an intellectual love of God. And for Spinoza this is tantamount to striving to be a good person. 
consider with Lady Ottoline-_-and Spinoza and Plato head the list: "... it would be an immense joy to read the things I care for with you-Plato and Spinoza come first in my affections." ${ }^{23}$ And only days before he funished The Problems of Philosophy, Russell writes on the centrality of Spinoza's thought in his life:

I loved reading the Spinoza with you. Ever since I first read Pollock's book which was when I was an undergraduate, Spinoza has been one of the most important people in my world. But I find his importance grows greater and greater to me-all my own thought makes me understand him better, and see the things he is meaning to say more clearly and with more knowledge of their importance. I felt an uneasiness until we had shared him. What I want to say is extraordinarily like what he says. He is the only one of the modern philosophers who has anything of that sort to say. (Letter \#168, II Aug. I9II)

As Russell sees it, Spinoza has helped further the relationship between himself and his lover. Ray Monk, in his biography of Russell, goes even further than Russell on this point, and suggests that Spinoza provided Russell with the framework to more fully grasp the nature of the relationship that existed between Lady Ottoline and himself in the summer of I9II:

The Spinozistic ideal of overcoming strife by transcending one's own finite ego and taking an "eternal" view of the world, and his experience of having been spiritually released by his love for Ottoline, had somehow become identified with the image of having been released from prison. It was as if Russell's love for Ottoline had become for him a living revelation of the religion that he had earlier outlined in "The Pilgrimage of Life": the religion of contemplation. (Monk, r: 227)

Unfortunately for Russell, his Spinozistic overtures had a limited success. While Russell was drawn to Spinoza's elaborate architectonic, with its commitment to an austere intellectual love of God, Lady Ottoline

${ }^{23}$ Letrer \#40, Io July t9in. In this letter Russell goes on to reassure Lady Ottoline that she need not be concerned if she does not initially understand the readings. What matters is the motivation to learn. "Don't be afraid you wouldn't understand enough to make it worth while. The thing that can't be acquired if one hasn't got it is interest in the subject. But you have that, and I could soon find out how to put things so that you would understand, if you always told me when you didn't understand." remained unmoved by the seventeenth-century intellectual religious philosopher. Or so the evidence suggests.

The correspondence strongly suggests that Lady Ottoline found Spinoza's philosophy hard to understand and difficult, if not impossible, to engage with. None of her responses to Russell's written explanations on Spinoza's thought is detailed, and many of the letters make it clear that she is struggling to comprehend his account of God. For instance, when Lady Ottoline responds to Russell's enthusiastic, reasonably detailed account of Spinoza's views (which he referred to as a "lecture"), she does so with a perfunctory remark: "... I like your Lecture on Spinoza immensely." ${ }^{24}$ Had she found Spinoza's thought significant, she would surely have been more forthcoming. A few months later, after a summer together considering the views of Spinoza, among other things, Lady Ottoline makes it abundantly clear that she still needs Russell's guidance: "I am anxious to read Spinoza over again with you. [sic] for now I feel you have shown me the essence of him and of his great vision and I want to make his thought real and living in me."2s After three months' coaching from a leading teacher of philosophy with a reputation for lucidity, Lady Ottoline is still dissatisfied with what she knows of Spinoza: she still wants "to make his thought real and living in me". For all his erudition and determination to help his lover grasp Spinoza's religious views, she remains unmoved. Her heroic efforts notwithstanding, Lady Ottoline had to concede that she could not relate to Spinoza's views on God. Russell had to attempt a different tack. Would it be possible to unite two seemingly disparate religious dimensions: one intellectual and the other emotional?

In the face of the failure of Spinoza to sufficiently engage his lover Russell turned his attention to another fount for inspiration: Lady Ottoline's significant emotional resources. Russell's search for a comprehensive religious perspective drew him to Lady Ottoline's spirituality and compassion. These essential attributes of her personality spurred Russell, in the summer of I9II, to write a second non-technical, popular text. But unlike the purely intellectual Problems of Philosophy, this text would

${ }^{24}$ Letter 710.081370 from 44, Bedford Square, Tuesday, 25 May 1911. She is responding to Russell's letter \#82, [24 May rgir].

${ }^{25}$ Letter 710.081466 , written from Peppard Cottage, Henley-on-Thames, I2 August. My emphasis. 
unashamedly focus on emotions and attempt a reconciliation between faith and the intellect. This work on reason, love and faith Russell called "The Religion of Contemplation", or "Prisons". The material must rank, as far as we can tell, ${ }^{26}$ as one of the most obscure of Russell's works, ${ }^{27}$ so what I say here must be regarded as highly speculative. Nevertheless, I think that some broad remarks on Prisons can still be made that will help us more clearly understand the influence of Lady Ottoline on Russell's igII conception of philosophy.

Prisons provided Russell the opportunity to blend his intellectual conception of religion with Lady Ottoline's more instinctive and emotional commitment to God. More specifically, this work, which both of them metaphorically referred to as their child, is Russell's attempt to accomplish two tasks:

(I) On the one hand, he is intent on establishing a harmony between religious belief and emotional love.

(2) On the other hand, Russell attempts to show that of the two, religious belief is more significant. ${ }^{28}$

Adopting the (Spinozistic) view that "religion consists in union with the universe", Russell argues that only an unfettered or objective soul can acquire knowledge and appreciation of our infinite universe. Individuals, therefore, who seek knowledge and appreciation of this universe, or notSelf-that is to say, those who seek to love God-must escape the restrictions of the instinctive, subjective Self. And the way to unshackle the chains of the Self is to develop an appreciation of the value of

${ }^{26}$ I put it like this because the original manuscript and its typed copies have been lost (or destroyed), and what remains are a few fragmentary pages and the essay "The Essence of Religion", which draws heavily on the ideas in Prisons. See the outline, drafts and essay in Papers 12: 102-9. However, there is reason to believe that some of the text was used in the final chapter of The Problems of Philosophy (see Papers I2: 100).

${ }_{27}$ Wittgenstein, for one, thought that Russell was "a traitor to the gospel of exactness, and wantonly used words vaguely" (SLBR, 1: 438 ).

${ }^{28}$ Russell expressed his disappointment over Prisons very soon after completing the manuscript. I suspect that part of his difficulties with this project was the problem of reconciling these two separate tasks. It appears that this issue also bothered Wittgenstein, for when he read "The Essence of Religion", he apparently complained that Russell was attempting to write about issues "too intimate for print" (Papers I2: III). religion.

As Russell sees it in 1911, the love of God makes possible all other forms of love. In his view, his love for Lady Ottoline is sustained by his love of God. In one of his letters to Lady Ottoline on the purported relationship between religious belief and emotional love, he writes that there

$\ldots$ is what one would call love of God if one believed in God, and in the long run I do not find that any other love can live if it comes into conflict with love of God. But love of you reinforces love of God and is strengthened by it. (Letter \#55, 4 May 19II; quoted in Forte, p. 82)

But the love of God, according to Russell, that is central to one's religious beliefs, is nothing but the love of, or reverence for, the universe, or the not-Self. And as emorional love, for him, is a manifestation of the instincts of the Self, his Prisons analysis of the relationship between faith and emotional love appears to be little more than a consideration of the relationship between the not-Self and the Self.

Russell's attempt to harmonize (and prioritize) intellectual religious belief with instinctive emotional love stirred Lady Ottoline's soul. After reading a portion of Prisons, on 28/29 July I9II she pens the following from Peppard Cottage:

I used to feel [that my thoughts] could not be told to anyone but now they come out to you - as if they were your thoughts - as if we were twin souls that had been wondering about the world and had just found each other and in the meeting we illumined each other. It is most sacred happiness. I feel now that our love would be but a half affair if we had not found this great soul union too but with it-it is utterly complete and satisfying. (Letter 710.08I453)

These remarks are especially important in our context. Not only do they suggest that Lady Ottoline thinks that Russell has been successful in his attempt to unify faith and emotional love, they also contain a not too subtle note on the origin of the idea to establish a harmony. In writing to Russell that her thoughts were emerging from him "as if they were your thoughts", Lady Ottoline is making it clear that in her view she is the source of the idea to establish harmony between faith and love. But the union that Lady Ottoline ecstatically refers to in her $28 / 29$ July letter is surely the same union that Russell later refers to in The Problems of

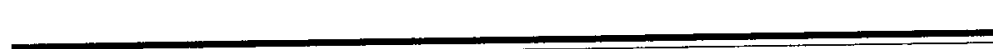


Philosophy. That is to say, this is surely an allusion to the harmony between the Self and the not-Self that Russell so eloquently elaborates on thirteen days later in the final chapter of the shilling shocker. ${ }^{29}$

Thus, if my analysis of The Problems of Philosophy is correct, and if my account of their correspondence is accurate, there can be little doubt that the tension in Russell's Igrr conception of philosophy is due in large measure to Lady Ottoline's influence, and to his wish to reconcile his thought to hers.

${ }^{29}$ Russell took two days to write Chapter xv of The Problems of Philosophy. On Friday morning, II August, he writes to Lady Ottoline:

I hope you are not very tired this mg, but I fear you must be. I am very fit-I wrote 2 pages of my chapter last might, and have written four more now. I shall easily get it done today. I enclose a letter from Gilbert Murray about the book, also a letter from the firm. Read Gilbert's first. You will see he is quite satisfied. He hadn't yet had the two chapters I read yesterday. You might give me back the letters on Tuesday. (Letter \#168)

We can be pretty sure that Russell is referring here to Chapter xv, as on I2 August he sends Gilbert Murray a letter from Lockeridge near Marlborough (presumably while staying with Alfred Whitehead) explaining that "Chap. Xv (the last) is written and staying with Alfed which " Russell was right for on is August Murray replies should reach you in a day or two." Russell was right-for on IS August Murray replies
from Fairhaven, Goathland: "My dear Bertie, I like xv immensely" (BRA REC. ACQ. 7I). 